\title{
Biosaintifika
}

Journal of Biology \& Biology Education

http://journal.unnes.ac.id/nju/index.php/biosaintifika

\section{Growth and Protein Content Establishment of Pleurotus ostreatus on Liquid and Solid Medium}

\author{
${ }^{\bowtie}$ Aris Mumpuni, Nuraeni Ekowati, Purnomowati, Endang Sri Purwati \\ DOI: 10.15294/biosaintifika.v9i3.11660 \\ Department of Microbiology, Faculty of Biology, Universitas Jenderal Soedirman, Indonesia
}

\section{History Article}

Received 24 September 2017 Approved 5 November 2017

Published 31 December 2017

\section{Keywords}

Fruitbody; Mycelial biomass; Pleurotus ostreatus; Protein

\begin{abstract}
Pleurotus ostreatus cultivation is performed using solid medium to harvest fruit body and using liquid medium to harvest mycelia in submerged culture. Modifying nutrients in the medium to increase protein content of the fruitbody and mycelia can be done through addition of nitrogen-containing materials. This study aims to determine: the appropriate composition of the liquid medium for high mycelial growth and protein content; and the exact composition of the solid medium to obtain high fruitbody product and protein content. The method was experimental with completely randomized design (CRD). The treatments were incubation of $P$. ostreatus on three types of liquid medium and four types of solid medium. The results showed that the optimal liquid medium composition for mycelial growth was Liquid Fermentation Medium 1 (FC1) with 10\% corn fluor, and the highest protein content was in Liquid Fermentation Medium $2(\mathrm{FC} 2=29.76 \%)$. While the optimal solid medium composition for fruitbody production was the medium with $3 \%$ corn starch supplement (TJ3), and the highest protein content was obtained from the medium without corn starch supplement (TJ0=24.69\%). The increase of mycelial and fruitbody weight from the medium with the addition of corn material indicated a prospective in cultivation process, however effort to increase protein content of the fruit body needs further research. Cultivating $P$. ostreatus in mycelial phase may take shorter incubation time, may be produced in mass production with less space consuming, and higher protein content than that by producing fruitbody.
\end{abstract}

\section{How to Cite}

Mumpuni, A., Ekowati, N., Purnomowati, P., \& Purwati, E. S. (2017). Growth and Protein Content Establishment of Pleurotus ostreatus on Liquid and Solid Medium. Biosaintifika: Journal of Biology \& Biology Education, 9(3), 572-578.

(C) 2017 Universitas Negeri Semarang $\bowtie$ Correspondence Author:

J1. HR Boenyamin 708, Grendeng, Purwokerto 53122

E-mail: arsmpn@yahoo.com
p-ISSN 2085-191X

e-ISSN 2338-7610 


\section{INTRODUCTION}

Pleurotus ostreatus (Jacq. Ex.Fr) Kummer or white oyster mushroom can grow on lignin and cellulose containing medium and so is easily found in weathered woods. People have been widely cultivating $P$. ostreatus as edible mushroom. It is charactized by high nutritional contents of $10.5-30.4 \%$ protein, $1.6-2.2 \%$ fat, $57.6-81.8 \%$ carbohydrates, $7.5-8,7 \%$ fiber, and $6.1-9.8 \%$ ash (Rashad et al. 2009). P. ostreatus also has medicinal properties through its bioactive compounds isolated from fruitbody that showed good activity in inhibiting the proliferation of cervix cancer cells (HeLa) (Ekowati et al., 2017). The nutrient content of fruitbody and mushroom mycelia is influenced by the constituent material of growth media, which is an important aspect to determine the quality of mushroom fruit body.

$P$. ostreatus is the second most cultivated edible mushroom worldwide after Agaricus bisporus. It has economic and ecological values and medicinal properties (Sánchez, 2010). The top level mushroom exporting country is China which reach $87 \%$, while mushroom export from Indonesia is only $4 \%$. Indonesia began to export edible mushroom in 2003, but to date there has been no rapid progress (Marshall and Nair, 2009). Up to 2008, the production of mushroom in China was still the highest in the world, reaching $70 \%$ of world production, while Indonesia was still below the top 10 (Vostrovský and Jablonská, 2011).

Studies to increase mushroom production needs to keep on going as Indonesia's mushroom production considerably low. According to Misachi (2017) it ranked $14^{\text {th }}$ in the world. Other data from Wakchaure (2014) China's mushrooms production was $1,568,523$ tons in 2007 , while Indonesia only produced 48,247 tons in the same year. While in 2011, (Misachi, 2017), China's mushrooms production increased to $5,008,850$ tons, on the other hand Indonesia sloped down to only produced 45,851 tons. Indonesia's ability in producing mushroom including that of $P$. ostreatus is still very low compared to other countries.

The low production of Indonesian mushrooms, especially $P$. ostreatus is due to inadequate capability of cultivation technology, as it is stated by Iriantinah (2014) that the inadequacy of technological performance influencing yield productivity; and nutrient-poor raw materials of growth media used on mushroom cultivation, as it is stated by Curvetto et al. (2002) that in fungus growth and development, both quality and quantity aspects (biological productivity and efficiency), are closely linked to nutrient type and growth conditions. Furthermore, according to Hoa et al. (2015) difference in mineral content of mushroom not only depended on mushroom species but also depended on substrates used. That was due to mineral concentration of substrate formulas. On the other hand, the electro conductivity of substrate is one of factors affected on mineral uptake of mushroom. Ekowati et al. (2011) stated that with the addition of minerals to the liquid fermentation medium, the yield of L. edodes bioactive compounds is higher than the yield from the standard medium. Amuneke et al. (2011) stated that the use of different growth substrates strongly affect the protein, carbohydrate and vitamin content of $P$. ostreatus.

$P$. ostreatus cultivation is usually performed using solid medium by harvesting the fruit body. Besides using solid medium, $P$. ostreatus can also be cultured using liquid medium by harvesting its mycelia. The mycelia are produced by different techniques with that of the fruit body. Mycelia production technique that has been developed recently is using a liquid medium with submerged culture. Good mycelia biomass growth in liquid medium should be supported by the availability of nutrients on the medium and enrichment of the medium with the addition of organic nitrogen sources, carbon sources and mineral additions which include macro and micro elements. The addition of nutrients to the culture medium will increase nutrient content in the mycelia, so that the mycelia can be used as spawn to obtain good quality and highly nutritious fruitbody.

Lomberh et al. (2002) reported that submerged cultivation in liquid media of mushroom mycelium is a promising method which can be used in novel biotechnological processes for obtaining pharmaceutical substances of anticancer, antiviral, immunomodulating, and antisclerotic action from fungal biomass and cultural liquids and also for the production of liquid spawn. As a result of the recent studies new data was obtained on the cultivation conditions which provide for fast growth and high productivity of the investigated strains in liquid media. The culture media including glucose, peptone, yeast and corn steep extract was proposed to be the best for most of the species investigated.

The addition of nutrients to the mushroom growth medium as an effort to increase protein content in the fruitbody can be done through addition of nitrogen-containing materials such as corn (Zea mays). Acording to Enyisi et al. (2014) the proximate composition of maize and maize products are of $44.8-69.6 \%$ carbohydrate; 11.6 - 20\% moisture contents; $4.5-9.87 ; 2.17-4.43$ 
fat; $2.10-26.77$ fibre; and $1.10-2.95 \%$ ash. Corn starch is applied as supplement sources of carbohydrates, fats and proteins.

Based on the above background, this research was performed to: 1) obtain liquid medium composition which can support the growth of $P$. ostreatus mycelia with high protein content; and 2) obtain solid medium composition which can support the formation of $P$. ostreatus fruitbody with high protein content. The result of this research may contribute ideas and practical technique on the mushroom cultivation that emphasize on gaining high yield of protein content either from mycelia or from the fruitbody.

\section{METHODS}

This research was held from April to October 2014 in the Laboratory of Mycology and Plant Pathology Faculty of Biology and the Laboratory of Organic Chemistry Faculty of Mathematics and Natural Sciences, Jenderal Soedirman University, Purwokerto, Indonesia. Elaborating $P$. ostreatus isolate (collection of Laboratory of Mycology and Plant Pathology), wood sawdust, rice bran, corn fluor, $\mathrm{CaCO} 3, \mathrm{CaSO} 4$, cotton, aluminium foil, alcohol $70 \%$, polypropylena plastic bag $(25 \times 15 \times 0.05 \mathrm{~cm})$, baglog collar, nose masker, hand glove, corn seed, Potato Dextrose Agar (PDA) medium, glucose, pepton, yeast extract, and malt extract.

Experimental method with Completely Randomized Design (CRD) and 4 replicates was used.

In phase 1 (liquid medium) the treatments were as follows :

\begin{tabular}{|c|c|}
\hline FC 1 & $\begin{array}{l}\text { Liquid fermentation medium } 1 \\
\text { (composition: }(\mathrm{g} / 1) \text { potato } 200.0 \\
\text { dextrose } 20.0 \text {; corn seed extract } \\
\text { 10.0). }\end{array}$ \\
\hline FC 2 & $\begin{array}{l}\text { Liquid fermentation medium } 2 \\
\text { (composition: }(\mathrm{g} / 1) \text { malt extract } \\
10.0 \text {; yeast extract 2.0; CaSO } 1.0 \text {; } \\
\text { rice bran extract } 5.0 \text {; dextrose } 10.0 \text { ). }\end{array}$ \\
\hline FC 3 & $\begin{array}{l}\text { Liquid fermentation medium } 3 \\
\text { (composition: }(\mathrm{g} / \mathrm{l}) \text { glucose } 40.0 \text {; } \\
\text { peptone 1.0; yeast exract 2.0; } \\
\text { KH2PO4 1.0; MgSO4.7H2O 0.2; } \\
\text { (NH4)SO4 5.0). }\end{array}$ \\
\hline
\end{tabular}

In phase 2 (solid medium) the treatments were as follows :

\begin{tabular}{cl}
\hline TJ $0: \begin{array}{l}0 \% \text { corn starch supplement on solid } \\
\text { growth medium }\end{array}$ \\
\hline TJ $1: \begin{array}{l}1 \% \text { corn starch supplement on solid } \\
\text { growth medium }\end{array}$ \\
\hline TJ $2: \begin{array}{l}2 \% \text { corn starch supplement on solid } \\
\text { growth medium }\end{array}$ \\
\hline TJ $3: \begin{array}{l}3 \% \text { corn starch supplement on solid } \\
\text { growth medium }\end{array}$
\end{tabular}

\section{Observation held on the first harvest.}

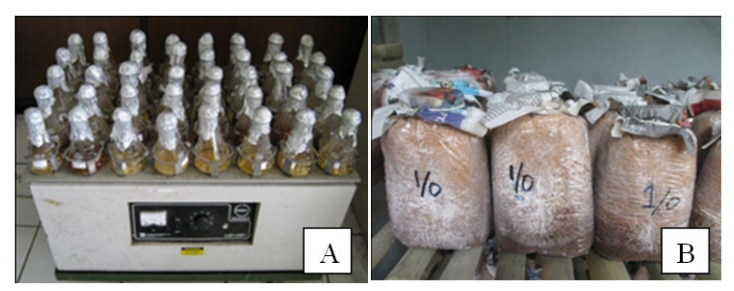

Figure 1. Incubation of $P$. ostreatus in liquid fermentation media (A); and solid media (B)

In phase 1 the experiment was conducted as follows : preparation of culture media for $P$. ostreatus mycelia, preparation of liquid culture media, inoculation of the isolate, incubation, harvesting, drying, and protein analysis (Figure 1A). While the experiment in phase 2 were as follows : preparation of growth medium for $P$. ostreatus fruit body, inoculation of spawn to the solid treatment media, incubation, harvesting of fruitbody, and protein analysis (Figure 1B). Media composition for phase 2 experiment were as follows (Table 1).

Data obtained were then analyzed using anova followed by Duncan Multiple Range Test (DMRT) at $5 \%$ error rate.

\section{RESULTS AND DISCUSSION}

The cultivation of $P$. ostreatus in three types of liquid fermentation medium shows that on the $28^{\text {th }}$ day the fungus has entered the stationary phase, so that secondary metabolites can be harvested. As the three types of medium used contain different nutrients, it is possible that the stationary phase were not be achieved at the same time. This resulted in difference of weight of harvested mycelia, either fresh or dry (Table 2 and Figure $2 \mathrm{~A}$ and $\mathrm{B}$ )

The highest weight of mycelia was ob- 
Tabel 1. Composition of solid medium material of $P$. ostreatus

\begin{tabular}{ccccccc}
\hline \multirow{2}{*}{ Treatment } & \multicolumn{7}{c}{ Composition } \\
\cline { 2 - 7 } & $\begin{array}{c}\text { Wood saw- } \\
\text { dust (kg) }\end{array}$ & $\begin{array}{c}\text { Rice bran } \\
(\mathrm{kg})\end{array}$ & $\begin{array}{c}\text { Gypsum } \\
(\mathrm{kg})\end{array}$ & $\begin{array}{c}\text { CaCO3 } \\
(\mathrm{kg})\end{array}$ & $\begin{array}{c}\text { TSP } \\
(\mathrm{kg})\end{array}$ & $\begin{array}{c}\text { Corn } \\
\text { flour }(\mathrm{kg})\end{array}$ \\
\hline TJ0 & 12.5 & 1.87 & 0.125 & 0.125 & 0.625 & 0 \\
$\mathrm{TJ} 1$ & 12.5 & 1.87 & 0.125 & 0.125 & 0.625 & 0.125 \\
$\mathrm{TJ} 2$ & 12.5 & 1.87 & 0.125 & 0.125 & 0.625 & 0.250 \\
TJ3 & 12.5 & 1.87 & 0.125 & 0.125 & 0.625 & 0.375 \\
\hline
\end{tabular}

Table 2. The mycelial weight and protein content of $P$. ostreatus mycelium cultured on three types of liquid fermentation medium

\begin{tabular}{cccc}
\hline Treatment & $\begin{array}{c}\text { Average of mycelial } \\
\text { fresh weight }(\mathrm{g})\end{array}$ & $\begin{array}{c}\text { Average of mycelial dry } \\
\text { weight }(\mathrm{g})\end{array}$ & $\begin{array}{c}\text { Average of mycelial pro- } \\
\text { tein content }(\%)\end{array}$ \\
\hline $\begin{array}{c}\text { Medium } \\
\text { FC1 }\end{array}$ & $11.71 \pm 0.24^{\mathrm{b}}$ & $1.01 \pm 0.30 \mathrm{~b}$ & $14.31 \pm 1.23 \mathrm{a}$ \\
$\begin{array}{c}\text { Medium } \\
\text { FC2 }\end{array}$ & $7.76 \pm 1.96 \mathrm{a}$ & $0.67 \pm 0.11 \mathrm{a}$ & $29.76 \pm 1.88 \mathrm{~b}$ \\
$\begin{array}{c}\text { Medium } \\
\text { FC3 }\end{array}$ & $6.70 \pm 1.89 \mathrm{a}$ & $0.71 \pm 0.14 \mathrm{a}$ & $27.06 \pm 1.40 \mathrm{~b}$
\end{tabular}

Note : numbers with the same alphabetic font in the same collumn are not significantly different

(DMRT 5\%)

tained from the medium of $\mathrm{FC} 1$ which was 11.71 $\mathrm{g}$, the weight was obtained from the liquid medium with the initial volume of $100 \mathrm{ml}$ and the final volume of $80 \mathrm{ml}$. If the medium is converted to 1 $\mathrm{L}$, it is estimated that the weight of mycelia will be $110,71 \mathrm{~g} / \mathrm{L}$. Medium FC1 is a natural medium because it uses potato extract and corn seeds extract and yet enriched with dextrose, in this medium the sources of carbon, nitrogen and mineral are highly available. Medium FC2 contains carbon, nitrogen, macronutrient and micronutrient sources, while FC3 medium contains high carbon source, little nitrogen source, and incomplete mineral content. This experiment showed that cultivation in natural medium spurred the growth of mycelium.

Protein content of mycelia biomass ranged $14.31-29.76 \%$ (Table 2.). According to Chang and Miles (2004) the protein content of P.ostreatus range is $10.5-30.4 \%$. This revealed that the protein content in mycelial biomass of $P$. ostreatus cultivated in the three types of media were good.

However, mycelial biomass weight on FC1 medium was not in line with its protein content as the capacity of mycelial growth in this medium was not proportional to its mycelial protein. Protein content of mycelium biomass was obtained high in FC2 and FC3 media. The data showed disadvantageous of using natural medium (FC1) of which the less measurable chemical composition of the medium affected the balance of nutri- ents and less suitable condition of the medium and results in low protein content in the mycelia. Meanwhile FC2 and FC3 media contained measurable minerals, which have very important function in metabolisms, especially as cofactors so that the formation of primary and secondary metabolites were optimal. Among the other two treatments, protein content in FC2 was the highest. This could be due to the medium cointains rice bran. It is conformed by Donini et al. (2009) that among the most used cultivation supplements, cereal brans are sources of organic nitrogen (N2), necessary to the growth of the mycelium mass, which may interfere in productiveness and biological efficiency of the fungus.

Protein content analysis was also performed on the fruit body cultured on four types of solid medium with different amount of corn flour supplement. It was observed that protein content in the fruitbody of $P$. ostreatus was not straightly proportional to the weight of the fruitbody obtained either. The percentage of protein content in the fruitbody ranged from 18.85 to $24.69 \%$, this showed that fruitbody protein was slightly lower when compared with the protein content in mycelial biomass.

Furthermore, the analysis of protein content was held to determine whether the high weight of fruitbody was also followed by high protein content. The analysis of fruitbody weight and its protein content is presented in Table 3. 
Table 3. Fresh weight and protein content of $P$. ostreatus fruitbody grown on solid medium.

\begin{tabular}{ccc}
\hline Treatment & $\begin{array}{c}\text { Average of fresh weight of } \\
\text { P. ostreatus fruitbody (g) }\end{array}$ & $\begin{array}{c}\text { Average of protein content } \\
\text { of P. ostreatus fruitbody (\%) }\end{array}$ \\
\hline $\begin{array}{c}\text { 0\% corn starch supplement } \\
\text { on solid growth medium }\end{array}$ & $67.33 \pm 9.07 \mathrm{a}$ & $24.69 \pm 0.72 \mathrm{c}$ \\
$\begin{array}{c}1 \% \text { corn starch supplement } \\
\text { on solid growth medium }\end{array}$ & $85.33 \pm 11.93 \mathrm{ab}$ & $18.85 \pm 0.73 \mathrm{a}$ \\
$\begin{array}{c}2 \% \text { corn starch supplement } \\
\text { on solid growth medium }\end{array}$ & $90.33 \pm 15.30 \mathrm{~b}$ & $20.82 \pm 0.18 \mathrm{ab}$ \\
$\begin{array}{c}\text { 3\% corn starch supplement } \\
\text { on solid growth medium }\end{array}$ & $94.00 \pm 8.88 \mathrm{~b}$ & $23.44 \pm 3.13 \mathrm{bc}$ \\
\hline
\end{tabular}

Note : numbers with the same alphabetic font in the same collumn are not significantly different (DMRT 5\%)

P. ostreatus cultured on four different solid medium showed that the supplementation of corn flour was able to increase fruitbody production, the more corn flour given, the higher the fruitbody yielded. Fruitbody weight ranged from $67.33-94.00 \mathrm{~g}$, this weight was obtained from the first harvest only (Figure 2B). This result was in consonant with the report of Jeznabadi et al. (2016) that the quality of P. eryngii was significantly affected by substrate ingredients. The type of substrate as well as the type and quantity of supplement appeared to have a substantial effect on prolonging the delayed-release nutrients. Carrasco-Gonz'alez et al. (2017) reviewed that the protein quality of $P$. ostreatus is one of its major strengths because it has high contents of all essential amino acids and excellent protein digestibility.
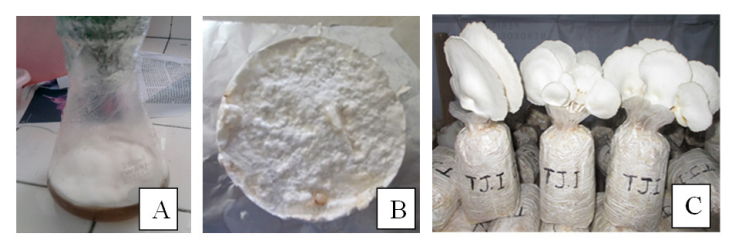

Figure 2. A twenty eighth-day mycelial incubation of $P$. ostreatus in liquid medium (A); harvested fresh mycelia of $P$. ostreatus (B); and readyto-harvest $P$. ostreatus fruitbody from solid media (C).

The weight of the fruitbody was not directly proportional to the content of protein in the fruitbody (Table 3.). The highest protein content was obtained from the addition of $0 \%$ corn flour or without corn fluor and from 3\% corn fluor treatment. The results showed that the addition of corn flour spur growth, the existing nutrients were used for the growth of mycelium until the formation of fruitbody, however, the nutrients were not enough to increase the protein content in the fruitbody.

Protein obtained from this experiment was a little bit lower than the protein content from fresh fruitbody $(30,20 \%)$ of $P$. florida grown on solid-mixed medium of cardboard and banana leaves, as it was reported by Tirkey (2017). The discrepancy maybe due to, as stated by Singh $e t$ al. (2008), several parameters that affect the enzyme production; however, its nitrogen source is a major factor.

The protein content in the fruitbody was not much different to the results of research reported by Patil et al. (2010) and Bonginkhosi et al. (2012) who states that the protein content of $P$. ostreatus range from 20.33 to $24.66 \%$. The amino acid content analysis showed that the mushroom contains high value of 19 kinds of amino acid both essential and non-essential, especially glutamic acid i.e. $64.02 \mathrm{mg} / 100 \mathrm{~g}$ fruit body. This high glutamic acid content that causes delicious taste in mushrooms.

Muhsrooms such as Agaricus bisporus, Pleurotus florida, Russula delica and Lyophyllum decastes are protein and fiber rich with low fat content. The ash content and carbohydrate content was less than other food from plant and animal origin (Teklit, 2015). This research revealed that the increase of fruitbody weight from the medium with the addition of corn flour indicated a prospective in cultivation process, as the increase in mushroom production is a common problem that is still difficult to overcome until now, the results of this study also provide great benefits for the development of mushroom cultivation industry, however effort to increase protein content of the fruit body needs further research, such as by modifying nutrient sources in the medium due to the results of this study were not yet consistent. As a nutriceutical foods, protein content in mushrooms is an ultimate parameter.

Proteins of Pleurotus sp. mushroom have 
superior quality because some of the members of this genus contains complete proteins with the well distribution of essential amino acids, as well as non-essential amino acids particularly gammaaminobutyric acid (GABA), that act as neurotransmitter and ornithine which is a precursor in the synthesis of arginine (Deepalakshmi and Mirunalini, 2014). In term of obtaining protein from $P$. ostreatus, cultivating the mushroom in mycelial phase in liquid media is a prospective effort to elaborate as it may take shorter incubation time, may be produced in mass production with less space consuming, and higher protein content than that by producing fruitbody. Mycelial biomass can be preserved in certain forms such as powder for further utilization as it was reported by Tupamahu and Budiarso (2017) that the addition of $1 \%$ P. ostreatus mushroom powder resulting in increased yoghurt quality, and the preferred yoghurt product by most of the panelists. It was then proven that the addition of the mushroom powder increase yoghurt quality and public acceptance.

\section{CONCLUSION}

Different composition of liquid and solid medium influenced growth and protein content of $P$. ostreatus. The optimal liquid medium for P.ostreatus mycelial growth (11.71g) was Liquid Fermentation Medium 1, while the highest protein content $(29.76 \%)$ was observed in Liquid Fermentation Medium 2. The optimal solid medium for $P$. ostreatus fruitbody production was the medium with $3 \%$ corn starch supplement, while the highest protein content was obtained from the medium without corn starch supplement $(24.69 \%)$.

\section{ACKNOWLEDGEMENT}

Thanks to Kemendikbud Dikti who has provided research fund of BOPTN Higher Education Research of Fiscal Year 2014 (Year II) through LPPM Unsoed Contract Number DIPA 023.04.2.189899/2014. Acknowledgments also to the Head of LPPM Unsoed and staff who have provided good facilities, information and cooperation, and the Dean of the Faculty of Biology Unsoed who has given permission and support to the implementation of this research.

\section{REFERENCES}

Amuneke E. H., Dike K. S., \& Ogbulie J. N. (2011). Cultivation of Pleurotus ostreatus: An edible mushroom from agro base waste products. Journal of Microbiology and Biotechnology Research, 1(3), 1-14.

Bonginkhosi, E. D., Diana, M. E., \& Masarirambi, M. T. (2012). Growth and Yield Response of Oyster Mushroom (Pleurotus ostreatus) Grown on Different Locally Available Substrates. Current Research Journal of Biological Sciences, 4(5), 623-629.

Carrasco-Gonz'alez, J. A., Serna-Sald'1var', S. O., \& Guti'errez-Uribe, J. A. (2017). Nutritional composition and nutraceutical properties of the Pleurotus fruiting bodies: Potencial use as food ingredient. Journal of Food Composition and Analysis, 58, 69-81.

Chang, S. T., \& Miles, P. G. (2004). Edible Mushrooms and Their Cultivation. CRC Press, Inc, Florida: Boca Raton.

Curvetto, N. R., Figlas, D., Devalis, R., Delmastro, S. (2002). Growth and productivity of different Pleurotus ostreatus strains on sunflower seed hulls supplemented with N-NH4+ and/or Mn (II). Bioresource Technology, 84(2), 171-176.

Deepalakshmi, K \& Mirunalini, S. (2014). Pleurotus ostreatus: an oyster mushroom with nutritional and medicinal properties. Journal of Biochemical Technology, 5(2), 718-726

Donini, L. P., Bernardi, E., Minotto, E., \& Nascimento, J. S. (2009). Growing Shimeji on elephant grass substrate supplemented with different types of sharps. Scientia Agraria, 1, 67-74

Ekowati N., Kasiamdari, R. S., Pusposendjojo, N., \& Soegihardjo, C. J. (2011). Daya Antimikroba Metabolit Bioaktif Jamur Shiitake (Lentinula edodes (Berk.) Pegler) yang Dikultur pada Tiga Jenis Medium Fermentasi. Majalah Obat Tradisional, 16(3), 132-137.

Ekowati, N., Mumpuni, A., \& Muljowati, J. S. (2017). Effectiveness of Pleurotus ostreatus Extract Through Cytotoxic Test and Apoptosis Mechanism of Cervical Carcer Cells. Biosaintifika: Journal of Biology \& Biology Education, 9(1), 148155.

Enyisi, I. S., Umoh, V. J., Whong, C. M. Z., Abdullahi, I. O., \& Alabi, O. (2014). Chemical and nutritional value of maize and maize products obtained from selected markets in Kaduna State, Nigeria. African Journal of Food Science and Technology, 5(4), 100-104.

Hoa, H. T., Wang, C. L., \& Wang, C. H., (2015). The Effects of Different Substrates on the Growth, Yield, and Nutritional Composition of Two Oyster Mushrooms (Pleurotus ostreatus and Pleurotus cystidiosus). Mycobiology, 43(4), 423-434.

Iriantinah, C. (2014). Strategi Pengembangan Komoditas Jamur Tiram Putih (Pleurotus florida) Di Kabupaten Nganjuk. Jurnal Manajemen Agribisnis, 14(2), 161-172.

Jeznabadi, E. K., Jafarpo, M., \& Ied. S. E. (2016). King oyster mushroom production using various sources of agricultural wastes in Iran. International Journal of Recycling of Organic Waste in 
Agriculture, 5(1), 17-24.

Lomberh, M. L., Solomko, E. F., Buchalo, A. S., \& Kirchhoff, B. (2002). Studies of medicinal mushrooms in submerged cultures. Mushroom Biology and Mushroom Products. Mushroom biology and mushroom products. UAEM, Cuernavaca, 367-377.

Marshall, E., \& Nair, N. G. T. (2009). Make money by growing mushrooms. Rural Infrastructure and Agro-Industries Division. Food and $\mathrm{Ag}$ riculture Organization of the United Nations (FAO). Rome.

Misachi, J. (2017). The World's Top Producers of Mushroom and Truffle. http://www.worldatlas.com/articles/the-world-s-top-producers-ofmushroom-and-truffle.html. Accessed 5 December 2017.

Patil, S. S., Ahmed, S. A., Telang, S. M., \& Baig, M. M. V. (2010). The nutritional value of Pleurotus ostreatus (Jacq.:Fr.) Kumm cultivated on different lignocellulosic agrowastes. Innovative Romanian Food Biotechnology, 7, 66-76.

Rashad M. M., Hala, M. A. Abeer, E., Mahmoud, \& Nooman, M. U. (2009). Nutritional Analysis and Enzyme Activities of Pleurotus Ostreatus Cultivated on Citrus Limonium and Carica Papaya Wastes. Australian Journal of Basic and Applied Sciences, 3(4), 3352-3360.

Sánchez, C. (2010). Cultivation of Pleurotus ostreatus and other edible mushrooms. Applied microbiology and biotechnology, 85(5), 1321-1337.

Sher, H., Al-Yemeni, M., \& Khan. K. (2011). Cultivation of the oyster mushroom (Pleurotus ostreatus
(Jacq.) P. Kumm.) in two different agroecological zones of Pakistan. African Journal of Biotechnology, 10(2), 183-188.

Singh, M. P., Pandey, V. K. Pandey, A. K., Srivastava, A. K., Vishwakarm, N. K., \& Singh, V. K. (2008). Production of xylanase by white rot fungi on wheat straw. Asian Journal of Microbiology, Biotechnology and Environmental Sciences, 10(4), 859-862.

Teklit, G. A. (2015). Chemical Composition and Nutritional Value of the Most Widely Used Mushrooms Cultivated in Mekelle Tigray Ethiopia. Nutrition and Food Sciences, 5, 408-411

Tirkey, V. J., Simon, S., \& Lal, A. A. (2017). Efficacy of different substrates on the growth, yield and nutritional composition of oyster mushroomPleurotus florida (Mont.) Singer. Journal of Pharmacognosy and Phytochemistry, 6(4), 1097-1100

Tupamahu, I. P. C. \& Budiarso, T. Y. (2017). The effect of oyster mushroom (Pleurotus ostreatus) powder as prebiotic agent on yoghurt quality. American Institute of Physics Conference Proceedings 1844, 030006 (2017)

Vostrovský, V., \& Jablonská, E. (2011). Geographical analysis of the mushroom Growing possibilities in the developing countries. Agricultura tropica Et Subtropica, 44(4), 229-234

Wakchaure, G. C. (2014). Production and Marketing of Mushrooms: Global and National Scenario. Indian Council of Agricultural Research. http:// www.world-atlas.com/answers. Accessed on 5 December 2017. 